\title{
TRANSITION ZONE IN SELJUQ DOME CHAMBERS
}

| Received August $7^{\text {th }}, 2019$ | Accepted October 23 ${ }^{\text {rd }}, 2019$ | Available online June 15 $5^{\text {th }}, 2020$ | DOI http://dx. doi.org/10.18860/jia.v6i1.7488

Amin Moradi

Research Center for Cultural Heritage and Tourism Iran

aminmoradi66@yahoo.com

\section{ABSTRACT}

Architecturally, the Seljuqs' dominion makes a significant shift from the PreIslamic Sassanid squinches into a sophisticated transition mechanism employed to change the walls of a square chamber to an octagonal base to set a dome. It initiated a new construction methodology to hybridize the previous experiences of Sassanid domes with new architectural tendencies since the prior understanding of the transition zone was a makeshift in quality. It is not consistent enough for future architectural adventures in creating larger structures. Although a cursory investigation of transition zones of Seljuq dome chambers in some respects reveals a relatively homogeneous framework, it has never meant the stagnation of architectural creativity in different parts of the Seljuk territory. On the other hand, the typology and loca schools of Seljuq transition zones of dome chambers have not been thoroughly considered by geographical centralism in Iran. For a better understanding of the standardization of various techniques considered in Seljuq architecture between the 11th and 12th centuries to span the cubic structure to a circular plan, this project is aimed to clarify three different schools of architectural articulation concerning transition zone in the Seljuq dome chambers. A structural analysis was conducted assuming several scenarios over Seljuq domes to clarify its geographical characteristics as well as static behaviors in different parts of Iran. This study shows that no dome has a regular mechanism of a transition zone, no two regions share the same approach, and three different empirical attitudes towards the transition zone would be enough to consider three architectural schools encompassing Northwest Iran, Alborz, and Central Iran, in which the difference lies in the basic elements of the construction of the transition zone rather than proportions.

KEYWORDS:

Islamic Architecture; Seljuq Architecture; Dome Chamber; Transition Zone; Static Analysis.

\section{INTRODUCTION}

After the Seljuk's defeat of Ghaznavid dynasty in $1040 A D$ and demolishing the Buyid dynasty in Baghdad, they established themselves as new protectors of Abbasid Caliphate in 1055 AD. Within fifty years, the Seljuqs created a vast empire, encompassing all of Iran, and much of Anatolia. Under Seljuq sultanate, Iran had a period of material, cultural wealth, as well as creativity in art and architecture [1].

Ever since the 1930s, when medieval Iranian architecture began to be studied in-depth, attempts have been made to define the characteristics of the typical Seljuq mosques in Iran [2]. Although the dome and vaults were prevalent in the Sassanian architecture in Iran [3] [4], the significant change from the preSeljuq system was the use of sophisticated transition zones in the Seljuq architecture. However, to embark upon a historical study on the initial employment of the idea of the transition area for dome chambers in architectural construction is a complex task, since it is not easy to pinpoint the place and time at which this mechanism was first developed. The Sassanid architecture was a pioneer in this filed where all of the royal structures were equipped with a series of consequence rounded arches in edges to support the dome [5]. Dietrich and O'Kane defined squinches as adjoining semi-domes that occurred in the Sassanid buildings in Kiz, Bozpar, Negar, and Sarvestan [6]. At the same time, it has been suggested that the appearance of the cutting-edge technology of domes on squinches originated from north-eastern Iran [7], where the change from the Sassanid squinch, rehabilitated due to the existence of an added rib in Samanid mausoleum (301-331/914-943), was dictated by utilitarian. Here, each squinch is composed of two concave niches separated by a kind of buttress [8], and this segmentation of the traditional squinch is intended as a new trend of strengthening the unit. Since this practice first flourished in northwestern Iran, it was long held that this area was, in general, the cradle of this technique where the spreading of this 
model by traveling architects along with the Seljuqs' invasions had developed and introduced this deformation through the Seljuq territories accepting local variations. This short essay will be focus on the topic of transition zones of Seljuqs' dome chambers in Iran.

The typological exploration of Seljuq's dome chambers mounted on a rehabilitated pre-Islamic transition zone is an issue that scholar's explanations have only covered some generalities of which the groundbreaking investigation of Hillenbrand is merely limited to Northwest Iran. Hence it is virtually impossible to confirm any hypothesis about its finality through the Seljuq dominion in Iran. Moreover, he suggested a homogeneous local school for the Seljuq domed mosque [2].

It is not surprising that there have been no clear boundaries between what has been known as the load -bearing unit of the shouldered arch and the description of a decorative member of muqarnas. Since what can be seen in any transition zone of dome chambers has the common characteristic of concave niches encompassing several lobes that are corbelled to create a stalactite shape form. From this point of view, many historians have used these terms counterintuitively [9][10][11][12] and others even went further by considering the transition zone as a result of the fragmentation of the squinch; stating that it ceased to be mere architectural supports, and became a recurring ornamental device in Islamic architecture [8]. Thus, misunderstanding towards the contrast between muqarnas and shouldered arch leads to the complicated and sometimes contradictory results. In a study undertaken by Pirniya, he proposed the theory of the architectural unity for all Seljuq buildings in Iran in which the composition of a transition zone in one point has followed the same language of other regions. After about half a century, the authenticity of this theory came under fire by the author. Then a structural analysis was conducted assuming several scenarios over Seljuq domes to clarify its geographical characteristics as well as static behaviors in different parts of Iran [9]. Here, our purpose is to discuss the local empirical approaches of different regions towards the transition zones in Iran.

\section{DISCUSSION}

\section{PRE SELJUQ TECHNOLOGY}

The period of transitions was critical in architecture [10]. According to the architectural evidence, one of the most precise mechanisms of reaching an octagonal base to set a dome had been appeared to be used in Baz-e-Hour. It should be taken into account as one of the earliest remnants of the Sassanids' Chahar-Tagi archetype, located in Khorasan, Northeast Iran [11], where a series of wooden beams are set in a corbelled manner in the corners of the square cubic. A continuous sequence of concentric arches in the Ardashir Palace (224-240 AD), as well as the Sarvestan royal building (420-438 AD) (Fig. 1), reveals the fact that this technique became more generalized during the Sassanid era due to the scarcity of wooden sources in Central Iran. Although the earliest employment of the conic squinch in Iran is a debate of studies, without a doubt, it has prevailed till the old Islamic ages. (Fig. 1)

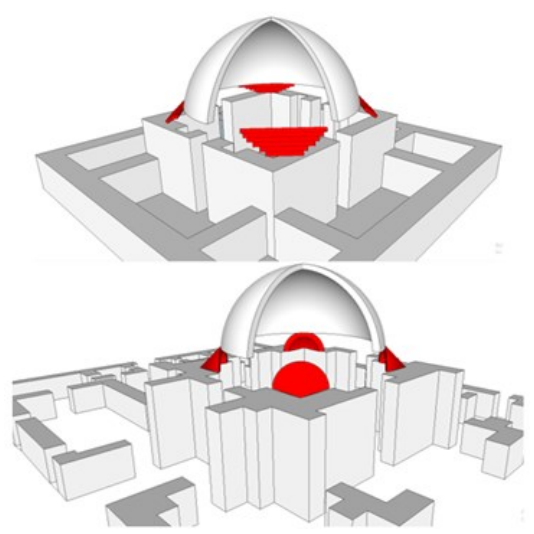

Figure. 1. Transition mechanism of pre-Seljuq structures. Up: Baze-Hour; Down: Sarvestan palace. (Author)

As a result of the building practice, by understanding how the thrust line affects the transition zone, the science of the construction technology of the squinch entered the next phase. It was conclusively proven that by loading a conic squinch, the thrust line would not only distribute through the conic geometry but also will be transferred through a straight direction along with a line, passing the apices of the squinch and reaching the edges, where the two load-bearing walls meet. Hence, the idea of channeling force through a semi-conic geometry had immediately been replaced by the modern tendency of focusing on the rib-shape buttresses. It became the most conspicuous element of the Samanid mausoleum (301-331/914-943). Thus, the rib unit was an indispensable device to support the crown of the pointed squinch, following an arithmetical procedure (Fig. 2).

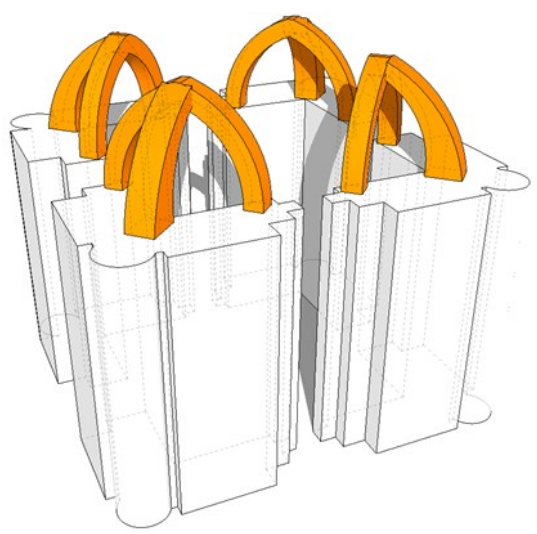

Figure 2. Transition mechanism in the Samanid mausoleum reinforced using a rib-shape buttress. (Author) 
Although it is difficult to interpret why and when masons concluded to assemble a reinforced squinch system, however, this is the earliest successful solution of a new attitude towards the transition zone [7]. Exploring the reflective ceiling plan of the Nain Mosque (fourth/tenth century), presenting a conservative set of double-rib buttresses holding the pointed arch frame in which the additional units act at the level of the voussoir of the squinch, is a proof of its acceptance among masonry projects. It is important to make this distinction that the transition challenge in Nain Mosque has never led to increasing the cubic dimensions. In other words, a connected set of reinforced pointed arches was sufficient to resize the diagonal of the square and hold the thrust of the dome (Fig. 3). Probably, the appearance of a similar rule in such a different place is a demonstration of traveling masters who were in search of the basic knowledge of construction as they saw fit.

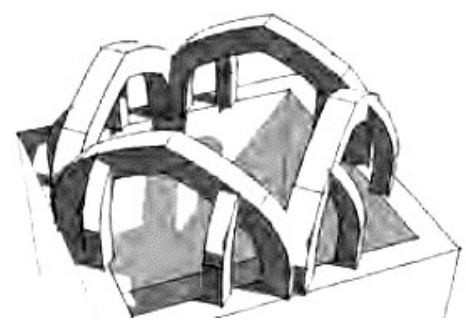

Figure 3. The composition of the transition zone in the Nain Mosque [7].

Very near Bukhara lies the village of Tim, the location of the Arab-Ata, a mausoleum built between $366 / 977-367 / 978$ [8]. Here, the simplicity of previous mechanisms of transition zones has been replaced by a modern arrangement of concave niches, depending on the particular circumstance of the units to remain in equilibrium. The result will be two segregated levels integrated as a unit. The first level, including two concave niches converging on the diagonal of the square, set the stage to mount the upper arch, enhancing the ability of thrust distribution, which affects the whole net [13]. A front view of this combination will present a tri-foiled arch in which this concept appeared as blind arches on the non-bearing sections of the dome chamber, providing a highly dynamic transition to the structure (Fig. 4).

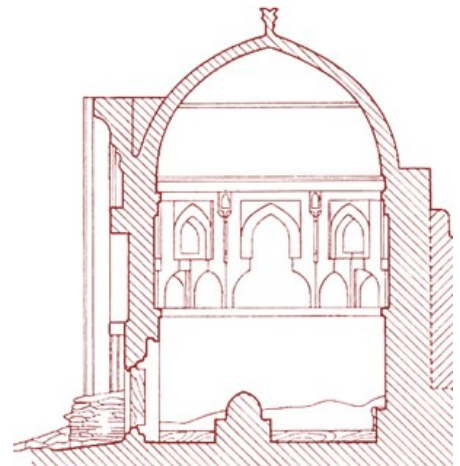

Figure 4. Transition zone in the Arab-Ata mausoleum (366/977) [8].
This technique is not an alien system in central Iran, where the specific feature of that appears in a new architectural language, assembled inside the pointed squinches. Of particular interest is the shrine of Davazdah-Imam at Yazd, built around two years before the beginning of the Seljuq invasion (429/1039). Using the analogy with the Arab-Ata, this structure signifies a multiplication of previous experiences. The transition zone for this mausoleum, as an empirical calculation, the pointed frame of the transition zone rehabilitated in connection with the shouldered arch system. Here, the relevant parameter to determine the maximum height of the transition zone is the dimensions of the pointed frame, which holds the niches to withstands against the thrust. Having considered all the structural benefits of what has been built, the presence of such a combination would suffice as a buttress and decoration without causing extra expenditures. This idea is less conservative than that of Samanid mausolea or Nain mosque, in which the single units support the squinch. Instead, a solid net of the shouldered arch facilitates it to endure when a great weight is loading the transition zone, and this allows to have a system of internal compressive forces that transmit the loads through this member (Fig 5).
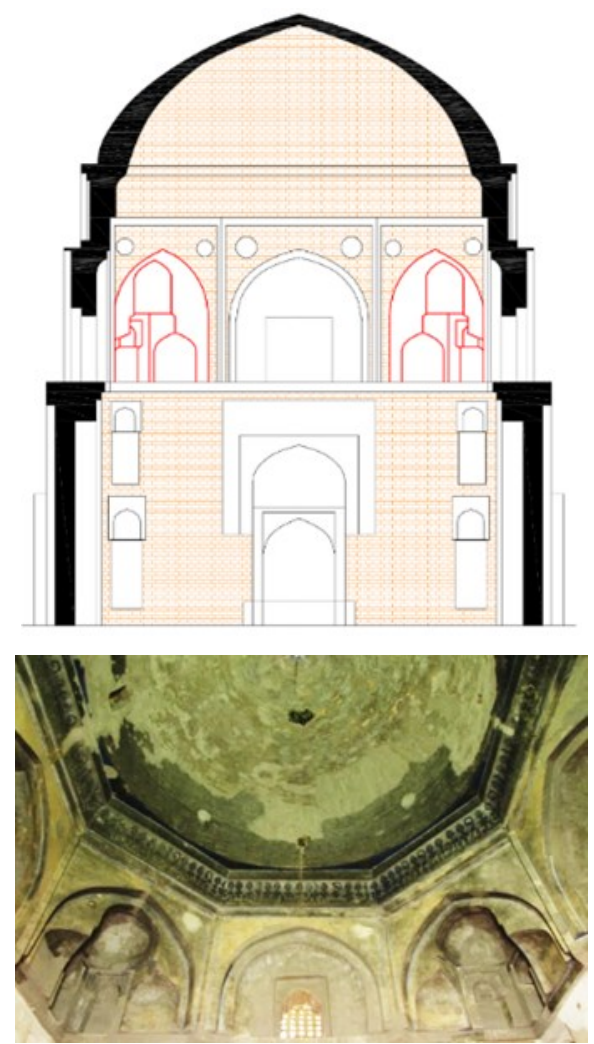

Figure 5. The transition zone of the Davazdah Imam Mausoleum (426/1037) at Yazd Province (Author).

\section{RELATIONS BETWEEN MATERIALS AND DIMENSION IN THE SELJUQ DOMINION}

In some cases, it is open to doubt whether this new technology did change the size of very early specimens of a new project or not. The dimensions of 
the dome chamber in the Samanid mausoleum (10*10m) does not reflect an architectural turn point in terms of diameter in analogy with the pre-Islamic project like those in Niasar $(14 * 14 \mathrm{~m})$, Negar $(12 * 12 \mathrm{~m})$, Sarvestan $(13 * 13 \mathrm{~m})$, and Firouzabad $(12 * 12 \mathrm{~m})$. One might propose the idea of requisite for rethinking the traditional transition zones of ancient engineering, considering the relatively expensive Sassanid technique of lime mortar that covered a huge percentage of high-quality stone materials as filler. It would have been replaced by brick structures, including a limited amount of lime, for a huge construction fee to keep costs down, evidently, as the Seljuq's solution to make the whole construction much lighter.

Although the lack of abundant architectural evidence makes it impossible to have a chronological study of this transition, concerning the Table 1., interestingly, the distribution of the stone and lime masonry in comparison with the brick and lime structures in Iran reveals the fact that the inaccessibility to the lime sources in the early Seljuq homelands in Northeast Iran [13] should be considered as one of the most probable reasons for a new attitude towards masonry. To put this into perspective, comparing the two contemporary structures of Gonbad-e-Jabaliyya in Kerman Province and Mumina Khatun in Nakhjivan, both dating back to 582/1203 AD, will clarify different approaches towards statical challenges where the $18 \mathrm{~m}$ height of Gonbad-eJabaliyya is a naive effort towards reaching a lofty structure in front of the $25 \mathrm{~m}$ height of Mumina Khatun's remains even without adding the approximate height of 8-10m of its demolished dome. The fears over displacement in Gonbad-e-Jabaliyya had forced the mason to think about thicker walls, where it caught more than $3 \mathrm{~m}$. With the help of new materials besides innovative architectural techniques in Mumina Khatun, the maximum width of the wall does not exceed more than $1 / 85 \mathrm{~m}$. It is not just a number, but a definite success due to the application of the new materials (brick and lime) in the Seljuq architecture. Otherwise, the architecture of the Seljuqs was incapable of any change for the better without material changes in principles and forms, while stone and lime mortar were inadequate for the further development without an entire change, since it was purely irreproachable to reach the concave shape of niches in the shouldered arch by carving the highquality stone materials, a complicated stereotomic problem. In general, the initiated experience of brick material was not reliable enough for much bigger domes. Still, the multiplicity of the conic squinch became the dominant feature of the Seljuq architecture when it was on its peak, where the excessive dimension of Nizam al-Mulk Dome $(15 \mathrm{~m})$ and Gazvin Mosque (15.2m) was absolutely out of touch during the Sassanid era [13].
Table 1. The approximate height and width of walls in Seljuq's tombs. (M: Materials; ID: Inner Diameter; H: Height; W: Width of Walls; D: Date of construction).

\begin{tabular}{|c|c|c|c|c|c|c|}
\hline$M$ & ID & H & w & Plan & D & Building \\
\hline Brick/lime & 11 & 10 & .07 & & 1166 & $\begin{array}{l}\text { Gopbad-e- } \\
\text { Serkh }\end{array}$ \\
\hline Brick/lime & 15 & 11 & 0.6 & & 1081 & $\begin{array}{l}\text { Kharagan } \\
\text { Tower }\end{array}$ \\
\hline Brick/lime & 16 & 20 & 1.45 & & 1155 & $\begin{array}{l}\text { Bori-e } \\
\text { Toghrol }\end{array}$ \\
\hline Brick/lime & 7.5 & 12 & 0.9 & & 1184 & $\begin{array}{l}\text { Bori-e- } \\
\text { Modayar }\end{array}$ \\
\hline Brick/lime & 5 & 13 & 0.8 & & 1201 & Se-Gonbad \\
\hline Brick/lime & 10 & 13 & 1.2 & & 1214 & $\begin{array}{l}\text { Gopobad-e- } \\
\text { Kabud }\end{array}$ \\
\hline Brick/lime & 5 & 10 & 0.6 & & 6th & $\begin{array}{l}\text { Borie- } \\
\text { Damavand }\end{array}$ \\
\hline Brick/lime & 7 & 14.5 & 0.9 & & 1111 & $\begin{array}{l}\text { Bori-e- } \\
\text { Mehroandust }\end{array}$ \\
\hline Brick/lime & 13.8 & 25 & 1.85 & & 1203 & $\begin{array}{l}\text { Mumina } \\
\text { Khatun }\end{array}$ \\
\hline Brick/lime & 8.5 & 11 & 1.45 & & 1050 & $\begin{array}{l}\text { Daxazdah } \\
\text { Imam }\end{array}$ \\
\hline Stone/lime & 8.9 & 12 & 1.5 & & 1069 & Gopbad-e-Ali \\
\hline Stone/lime & 7 & 15 & 1.57 & & 1164 & $\begin{array}{l}\text { Sheikh } \\
\text { Lenaid }\end{array}$ \\
\hline Stone/lime & 11 & 18 & 3.10 & & 1203 & $\begin{array}{l}\text { Gopobad-e- } \\
\text { dabaliyxa }\end{array}$ \\
\hline
\end{tabular}

\section{SELJUQ TECHNOLOGY OF TRANSTITION ZONE}

Undoubtedly, a fresh feeling in construction technology appeared during the Seljuq dominion when the principle distinction between the height of the buildings depends on their revolutionary system of transition zones. It was vital to create well-deserved structures to reflect the Seljuq magnificence. A critical fact about the political transition from east to the west of Iran during the Seljuq dominion is a massive range of possibilities to adapt and develop the prior architectural traditions, like those in the buildings mentioned above of Ismail Samanid and Arab-Ata mausoleum. The evolution of the transition zones 
during Seljuq architecture begins with the earliest departure from the construction forms of the preSeljuq ages in northwest Iran. Likewise, Seljuq masons had the opportunity to experience different schools, including those edifices which employ various principles of local knowledge related to the transition zone. In other words, the Seljuq mechanism of transition zone found its full expression as a standard system on the previous monuments, from whence it spread through its territory, where the seed had already been sown in the powerful architecture poles like central and northwest Iran. This approximate simultaneous attitude had never followed the same rules in the whole Seljuq dominion. When we come to Seljuq's time, however, the localization determines the architectural forms, and the articulation of the transition zone is not an exception. To spotlight various tendencies over this architectural unit in Seljuq dominion, three distinguishable school related to the transition zone has been classified due to the field studies.

\section{NORTHWEST IRAN}

Concerning the Seljuq boundaries, in particular the strategic importance of the frontlines, Northwest Iran would be on the top, since this place had always played a vital role in spreading Seljuq policies to the west [13]. According to the historians, this point of Iran experienced the collusion of Muslims (Seljuqs) and Non-Muslims (the Byzantine) [16], where the unprecedented number of unknown tombs to commemorate those ceased in the holy war (Jahad) is a testimony for its sacredness. A superficial review of the Seljuq architectural remnant in this region, such as Marand Mosque (485/1106), Urmia Mosque (5th century), Se-Gonbad (580/1201), Borj-e-Modavr (563/1184), Gonbad-e-Sorkh (542/1163), Gonbad-eKabud (593/1241), and Mumina Khatun (582/1203) will reveal the fact that despite other parts of Iran, a large variety of plans from square to octagonal, dodecahedral, and circular were common. Since the challenge of transition has a close tie with the geometry of plan, as well as the number of sides, the science of transition from dodecahedron or even octagon to a circle base would not follow controversial arrangements. Thus, from a structural point of view, a radial series of pointed arches would suffice to create a dome in Borj-e-Modaver (the circular tower), Gonbad-e -Kabud, and Mumina Khatun, while in other specimens, the existence of a capable transition mechanism would be inevitable owing to the geometry.

It might be suggested that the limited breadth of Gonbad-e-Sorkh and Borj-e-Modavar ruled the employment of a simple shouldered arch to support the dome while considering the idea of assembling the dome in the Marand Mosque (diameter $\approx 7.6 \mathrm{~m}$ ) and Urmia Mosque (diameter $\approx 10.7 \mathrm{~m}$ ). The load-bearing concaved facets mounted on each other in two levels precisely would devalue this assumption proposing the specific architectural genre of the transition zone in Northwest Iran (Fig 6).

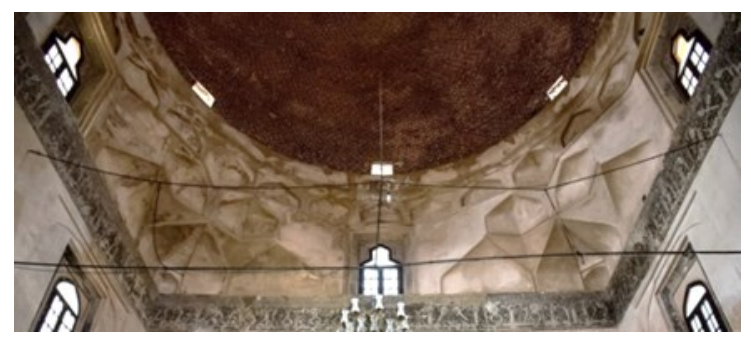

Figure 6. Transition mechanism in the Urmia mosque.

In Marand mosque, the transition zone is lavishly decorated, which the detail work is strong enough to accept this speculation that close relations between Tabriz (the major city during the Seljuq era) and Marand (the most important stop before Tabriz) would explain this aristocratic attitude toward this mosque. The authenticity of this theory will be doubled if we keep in mind that during the Mongol Invasion's a highly-decorated stucco Mihrab has been added to this mosque. Tabriz was served as the capital of the Islamic world beyond comparison. What differentiates the principles of the transition zone in this mosque with Urmia is the continues-tangled net of concaved niches, circling the circumference of the cubic dome chamber even in the middle of the sides. It would have led to structural unity and equilibrium. Thus, its structural safety is ample.

On the contrary, the considerable size of sides in the Urmia Mosque, in comparison with Marand Mosque, has dictated the lack of such structural continuity. By its very nature, in Urmia Mosque, the middle of the sides will tend to yield downward, making it relatively vulnerable. Although the application of the unilateral brick material in both cases provides the single resistance against compression, not tension, as a consequence a similar appearance of the transition zone in Marand (Fig 7) would reflect a better behavior in comparison with the discontinues and heterogeneous system of Urmia, merely covering the edges. Thus, in Marand, in technical terms, the arch is statically hyperstatic or redundant.

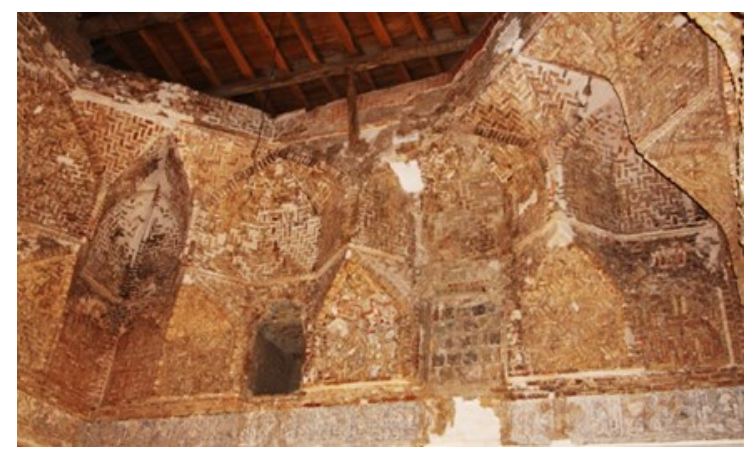

Figure 7. Marand Mosque is an interconnected set of concave units in the transition zone.

28 | Journal of Islamic Architecture, 6[1] June 2020 


\section{ALBORZ SCHOOL}

Not far from Northwest Iran, a collection of unique Seljuq buildings encompassing three mosques in Gazvin (509/1130), Sujas (5th/11th century), Qorva (575/1196), and seven towers of Toghrol (534/1155), Kharragan (Eastern 460/1081, Western 486/1107), Mehmandust (490/1111), Chehel-Dokhtaran (464/1085), Lajim (443/1064), and Damavand (6th century) holds the second powerful construction pole of the fifth/ eleventh century. It stretched from the east most point of Northwest Iran to the Raga (the important capital of Seljuqs') and its surrounding parallel to the Alborz mountains. In terms of diameter, although those of Qorva $(5.5 \mathrm{~m})$ and Sujas $(9.2 \mathrm{~m})$ are noticeably smaller, the Qazvin dome chamber $(15.2 \mathrm{~m})$ is of a size to challenge in comparison with the Isfahan Mosque (15m) [2].

A purely different architectural statement appears in the Toghrol tower in which the diameter of the structure $(16 \mathrm{~m})$ has exceeded the defined norms with the help of the circular plan, being well-deserved to be titled as a mega-structure [13]. Like polyhedron structures of Northwest Iran, the criterion of geometry governs conveniently as an absolute guaranty for the stability of the transition zone in Kharragan, Mehmandust, and Damavand without overwhelming static challenges.

Although Byzantine structures were of crucial influence to the deformation of early Islamic samples [17], the impact of the Sassanid modules of the transition zone in this region is irrefutable. The articulation of a pointed frame supported by two concaved niches, the most common interpretation for this physical appearance, lies in what should be titled as the "Architectural Obligation." The simplest method to fill the distance between the crown of the pointed frame and edges, using masonry, will create such geometry. A feature that had no hitherto existed in northwest Iran, which narrates the similar structural caprice of those in the Ardashir palace, Niasar temple, and Sarvestan royal building. Details are noteworthy, as a radial series of smaller arches employed at the uppermost level of the transition zone before the circular base is the constant feature of this school. Although this technique was famed exclusively along with the Alborz mountain range, the absence of a similar module in other parts of Iran would be enough to verify such a rule as a conspicuous characteristic of this region.

What is fascinating about this school is the close fraction of the height to the width of the pointed frame of the transition zone in Qorva (1:1.3), Sujas (1:1.4), and Gazvin (1:1.36) which this promulgate a statical edict. The eccentric increase in vertical units would cause severe damages parallel to buckling, displacement, and deformation, without thinking about buttressing members. Hence, this ratio could not overshoot this standard, which means that the pointed frame higher than this proportion cannot be prepared. Otherwise, by scaling up, the safety coefficient will decrease as a result of the inferior proportions.

Table 2. Architectural similarities between the Sassanid transition zones and Seljuq's methods in the Alborz School.

\begin{tabular}{|c|c|c|c|}
\hline Building & $\begin{array}{c}\text { Ardestan } \\
\text { Palace }\end{array}$ & $\begin{array}{c}\text { Sarvestan } \\
\text { Palace }\end{array}$ & $\begin{array}{c}\text { Niasar Tem- } \\
\text { ple }\end{array}$ \\
\hline $\begin{array}{l}\text { Sassanid } \\
\text { Mecha- } \\
\text { nism of } \\
\text { Transition } \\
\text { zone }\end{array}$ & & & \\
\hline & $\begin{array}{l}\text { Gazvin } \\
\text { mosque }\end{array}$ & Qorva mosq & $\begin{array}{c}\text { Sujas } \\
\text { mosque }\end{array}$ \\
\hline $\begin{array}{l}\text { Seljuq } \\
\text { Mecha- } \\
\text { nism of } \\
\text { transition } \\
\text { zone in } \\
\text { Alborz } \\
\text { School }\end{array}$ & & & \\
\hline
\end{tabular}

In the case of thrust distribution, two distinguished approaches have been followed in Northwest Iran versus Alborz School. It is only necessary to have some familiarity with the distribution of forces to understand the concept. As figure 8. demonstrates, the paradox of transmission of force to overcome thrust is a real contradiction in Marand and Qazvin's mosque. It is hard to ensure that the overall form of the transition zone in Alborz School is more than a modified version of the Sassanid's retained techniques in which the load will affect the pointed frame-breaking in tow branches, where the vertical thrust is constant (Fig 8). Although this method might present a saving of masonry, statically, the point of application of the thrust will lie within the thickness of the pointed frame. Here, the main threat lies in the fact that, theoretically, the criterion of a single arch is unsafe, in particular, when the structure grows in size; because the frame will be dangerously near the collapse situation due to the lack of any admissible support. On the contrary, a tangled set of concave members in Marand Mosque is not only safe but that it has surplus by increasing the number of these units which this would ease the thrust transmission to the most loaded parts (in general, the bearing walls) without a diminution of the safety. As a consequence, the interconnected members will distribute the thrust line along with the brick net, whereas in every lower joint, this fraction will decrease to a half (Fig 8. left).

The characteristic of the dome chambers in the Northwest School, as well as the Alborz School, does not necessarily warrant a lofty elevation owing to some architectural obstacles related to the composition of the transition zone. Following the numerical results, the limited maximum height of 
approximate 10m (Urmia mosque) for the total height of dome chambers in Northwest Iran might have reflected the verification failure of the safety efficiency for larger proportions in this region. However, the successful combination of the above-mentioned techniques leads to the new patterns of equilibrium, which appear in central Iran, where a huge percentage of high rise structures impose a substantial change in the theory of structure.
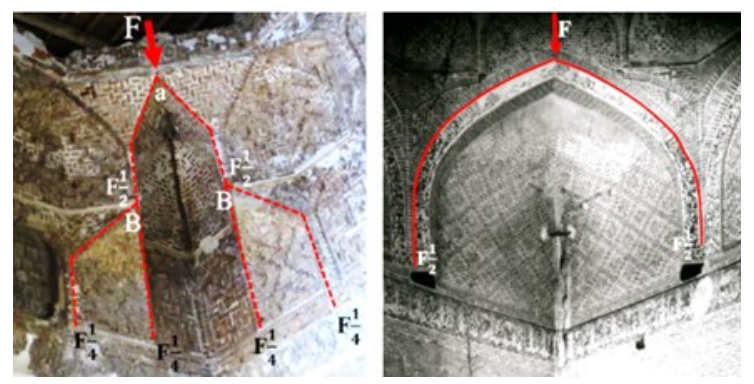

Figure 8. The design strategy of the transition zone showing how thrust affects this part of the structure in Marand mosque (left) and Qazvin mosque (right). Statically, the single frame is on the verge of collapse without the material of better quality.

\section{CENTRAL IRAN}

The intriguing obligation in which masons were forced to create lofty structures in central Iran, as the religious pole of the Seljuqs' [18], made the quality enhancement of the transition zone central to their construction strategies. Hence, this region has gained its reputation as an axis of highly proportional buildings in comparison with the two schools mentioned above [13]. Central Iran offers further developments in the transition zone, focusing on the combination of the two features of the triangle shouldered arch with the pointed frame. This synthetic approach breathing life back into Iranian architecture after the stop-start campaign of the early Islamic ages. The idea of this combination first departed from Isfahan, where an excellent example of this type is presented by the south-east (Nizam-al Mulk) and north -east (Taj-al Mulk) domes of Isfahan's Mosque, built-in $464 / 1072$ and $480 / 1088$ respectively. Here, the squinch comprises four niches, the central one acting as a segment of barrel vault and supported by a plain squinch, while the lateral niches retain the pointed concave design. Above the octagon proper is a sixteensided area before the base of the hemisphere dome itself; this latter structural solution like a "squinch net" has enriched the zone of transition [8], and the whole complex is used to stabilize the pointed frame.

In most cases, each lobe is broken up by a series of sub-squinches, also lobbed, which increase the apparent depth of the squinch and constitute a varied array of facets set at different angles [2]; that succor and distribute the vertical loads of the dome. An arrangement is hitherto known only, particularly in Central Iran. The more lobs that the transition zone consists of, the more stability the shouldered arch net guaranteed [13]. In terms of dimension, Gazvin Mosque broke a tie with Isfahan Mosque with the help of an enhanced transition zone, as well as the rib technique supporting the dome. The vivid difference between the crown of the dome in the Isfahan mosque- Maximum height of the Gazvin mosque is approximately $23 \mathrm{~m}$ while this amount is about more than $34 \mathrm{~m}$ for the Isfahan's mosque- introduced it as a lambency of sophistication.

Table 3. Transition area in Seljuqs' dome chambers of Iran (Author

\begin{tabular}{|c|c|c|c|c|c|}
\hline $\begin{array}{l}\text { Height } \\
\text { (m) }\end{array}$ & $\begin{array}{l}\text { Transition } \\
\text { Zone }\end{array}$ & Pic & Section & Date & \\
\hline 5.77 & $\begin{array}{c}\text { Squinch } \\
+ \\
\text { Shouldered } \\
\text { Arch }\end{array}$ & & & 1094 & $\begin{array}{l}\text { Nizam-al } \\
\text { Mulk }\end{array}$ \\
\hline $5-82$ & $\begin{array}{c}\text { Squinch } \\
+ \\
\text { Shouldered } \\
\text { Arch }\end{array}$ & & & 1102 & Taj-al Mulk \\
\hline 5.10 & $\begin{array}{c}\text { Squinch } \\
+ \\
\text { Shouldered } \\
\text { Arch }\end{array}$ & & & 1170 & Ardestan \\
\hline 5.32 & $\begin{array}{c}\text { Squinch } \\
+ \\
\text { Shouldered } \\
\text { Arch }\end{array}$ & & & 1151 & Zavareh \\
\hline 5.13 & $\begin{array}{c}\text { Squinch } \\
+ \\
\text { Shouldered } \\
\text { Arch }\end{array}$ & & & mg & Barsian \\
\hline 5.90 & $\begin{array}{l}\text { Squinch } \\
+ \\
\text { Shouldered } \\
\text { Arch }\end{array}$ & & & 133 & Colpayegan \\
\hline 4.80 & $\begin{array}{l}\text { Squinch } \\
\text { (Single } \\
\text { frame) }\end{array}$ & & & 130 & Qazvin \\
\hline $3-92$ & $\begin{array}{l}\text { Squinch } \\
\text { (Single } \\
\text { frame) }\end{array}$ & & & "190 & Qorveh \\
\hline 3.88 & $\begin{array}{l}\text { Squinch } \\
\text { (Single } \\
\text { frame) }\end{array}$ & & & sth & Sojas \\
\hline 3.2. & $\begin{array}{c}\text { Shouldered } \\
\text { Arch }\end{array}$ & & & 100 & Marand \\
\hline $3.4^{8}$ & $\begin{array}{l}\text { Shouldered } \\
\text { Arch }\end{array}$ & & & & Urmia \\
\hline
\end{tabular}


The architectural revivals of the combination of the transition zone strengthened by the presence of a triangular shouldered arch net have immediately become predominant in central Iran. Besides Isfahan domed mosques, a collection of this synthetic method in Ardestan Mosque (555/1176), Zavare Mosque (530/1151), Barsiyan Mosque (498/1119), and Golpayegan Mosque (512/1133) is strong enough to consider the hybridization of a simple shouldered arch (Northwest Iran) and the single-pointed arc (Alborz School) in Central Iran. In this school, although each building is a successful experiment, the fraction of the height to the diameter of the transition zone in the Nizam-al Mulk's dome (2:41) reveals the most ambitious architectural demands for an imperial project while this fraction is disappointingly small in other specimens (Table 3 ).

\section{CONCLUSION}

The development of Seljuq architecture was revolutionary, an explosion of structural creativity that never reflected a purely Darwinist theory independent from exploring and developing preexisting architectural theories. From this point of view, the Seljuq transition zone is, in general, the old pre-Seljuq system, modified by the requirements of the difficulties of the new demand for construction. The higher structures of the Seljuq era needed amenities which Sassanid architecture could not afford. As a result, Seljuq architecture adapted and developed the Sassanid techniques, but this diversity proceeded smoothly. Although Hillenbrand states that no single type of transition mechanism had predominance throughout Iran during the Seljuq dominion and the factors which led to the adoption of one or a different kind in a given case are still obscure, this understanding of transition zone is incorrect. A cursory investigation of the transition zones in the Seljuq era will be convenient to conclude that, firstly, no dome has a regular mechanism of a transition zone; secondly, no two regions share the same approach. Finally, three different empirical attitudes towards the transition zone would be enough to consider three architectural schools encompassing Northwest Iran, Alborz, and Central Iran, in which the difference lies in the basic elements of the construction of the transition zone rather than proportions. The local development of architectural experiences in these three classes is not categorized by periodical purification, while geographical variations in the science of construction are inevitable. The first school, which one might for convenience call the" Azerbaijan School," has prominent points of difference from the others in which the significance character of the transition zone is an interconnected concaved niche. Although this guaranteed the distribution of thrust line amazingly, it has its limitations. An initial architectural calculation seems to confirm that the number of triangle lobs in this school had never exceeded the norm of two layers. Thus, the architectural outputs are noticeably smaller. The Alborz school presents an involuntary imitation of the Sassanid technique.

In contrast, a structural obligation, the ratio of width to the height in the pointed frame of the transition zone, has always shown a concerted attempt to keep the same coefficient ratio $(\approx$ l:1.4). An architectural correction of the aforementioned practices was necessary to reach the higher elevations. In Isfahan, the experiences of other schools became incorporated into each other, introducing a pointed frame supported by the shouldered arch net. Having followed the Isfahan schools' instruction, the result will be a mutant mechanism for the transition zone to reach higher structures.

\section{REFERENCES}

[1] C. E. Bosworth, Historic cities of the Islamic world, Boston: Leiden, 2007.

[2] R. Hillenbrand, "Saljuq Dome Chambers in Northwest Iran," British Institute of Persian Studies, No. 14, pp. 93-102. 1976.

[3] V. F. Reber, History of Ancient Art, J. T. Clarke, New York: Harper and Brothers, 1882.

[4] L. Woolley, The art of the Middle East including Persia, Mesopotamia and Palestine, New York: Crown Publishers, 1961.

[5] A. Godard, The Art of Iran, New York: Praeger. 1965.

[6] D. Huff and B. O'Kane, "CHAHARTAG," Encyclopedia Iranica, 1990. [Online]. Available: http://www.iranicaonline.org/articles/ chahartag. [Accessed: 01-Jul-2019].

[7] H. Safaipour, "Understanding the Identity of Shouldered Arch by Analyzing the Initial Specimens". Journal of Iranian architecture studies. No. 5, pp. 5-19. 2013.

[8] A. Carrillo, "The Sassanian Tradition in Abbasid Art: squinch fragmentation as the structural origin of the muqarnas," Mirabilia. Vol. 21, no. 1, pp.201-226, 2016.

[9] J. Bloom, "The Introduction of the Muqarnas into Egypt". Muqarnas: An Annual on Islamic Art and Architecture. No. 5, pp. 21-28, 1988.

[10] K. A. C. Creswell, The Muslim architecture of Egypt, Oxford: Charendon Press. 1952.

[11] R. Ettinghausen and O. Grabar, Arte $y$ Arqitectura de Islam 650-1250, Madrid: Catedra. 2000.

[12] O. Grabar, "La formacion del arte islamico". Madrid: Catedra, 1986.

[13] A. Moradi and B. Omrani, The review of the Ilkhanid architecture in Northwest Iran, Tehran: RICHT (Research center for cultural heritage organization), 2019.

[14] S. Huerta, "Technical Challenges in the Construction of Gothic Vault: The Gothic Theory Structural Design," in Construction 
Techniques in the Age of Historicism. From Theories of Gothic Structures to Building Sites in the 19th Century, Munich: Hirmer, 2012, pp. 162 -195 .

[15] A. U. Pope, Persian Architecture, Iran: Soroush Press. 1982.

[16] V. M. Zaporozhets, The Seljuks, Germany: Hannover. 2012.
[17] S. K. Yildiz, "A Review of Byzantine Studies and Architectural Historiography in Turkey". Metu. No. 2, Vol. 28, pp.63-80. 2011.

[18] M. Morsalpour, "Reflection of Iranian Governance Pattern in Khaje Nizam Al-Mulk's Syasat-Nama," International journal of humanities, Vol. 24, no. 4, pp. 43-57. 2018. 